\title{
THE IMPORTANCE OF TAX AMNESTY POLICY IN ORDER TO OVERCOME TAX EVASION IN INDONESIA
}

\author{
Imas Sholihah \\ Centre of Research and Development at Attorney General's Office of Republic of Indonesia \\ E-mail: imas.sholihah1708@gmail.com
}

\begin{abstract}
Fundamental problems of taxation in Indonesia is a low tax ratio and management of the tax system has not been well ordered, especially the handling of the tax evaders. Tax amnesty policy is present as one of the solutions of the problems of taxation and is part of the tax reform. There are pros and cons to this policy as it pertains to the settings in the Tax Forgiveness Act is considered less sense of fairness and legal certainty and are vulnerable to abuse of authority. This policy became important although it is less sense of fairness if the review facilities subject to tax amnesty even though the state would get the revenue the state in large numbers in a short period of short-term benefits, but if managed by the management and human resources professionals, socialization, and optimized control, a long-term positive impact to minimize state income tax evasion.
\end{abstract}

Keywords: tax amnesty, policy, tax evaders

\begin{abstract}
Abstrak
Persoalan mendasar dari perpajakan di indonesia adalah tax ratio yang rendah dan manajemen sistem perpajakan yang belum tertata dengan baik terutama penanganan terhadap para penghindar pajak. Kebijakan tax amnesty hadir sebagai salah satu solusi dari persoalan perpajakan dan merupakan bagian dari reformasi perpajakan. Terdapat pro-kontra terhadap kebijakan ini karena berkaitan dengan pengaturan dalam UU Pengampunan Pajak yang dinilai kurang memenuhi rasa keadilan dan kepastian hukum serta rentan terhadap penyalahgunaan kewenangan. Kebijakan ini menjadi penting walaupun dirasa kurang memenuhi rasa keadilan jika ditinjau fasilitas subyek pengampunan pajak meski negara akan mendapatkan pendapatan negara dalam jumlah yang besar dengan waktu yang singkat dari manfaat jangka pendek, namun jika dikelola dengan manajemen dan sumber daya manusia yang profesional, sosialisasi, dan pengawasan yang optimal, secara jangka panjang berampak positif terhadap pendapatan negara meminimalisir penghindaran pajak.
\end{abstract}

Kata kunci: tax amnesty, kebijakan, penghindar pajak

\section{Introduction}

Taxes are needed as a major source of state revenue. Target Revenues from taxes in 2016 are amounted Rp1.546,7 trillion, from the state budget in 2016 , it is expected that $74.6 \%$ of state revenues derived from taxes, $10.2 \%$ from the customs and excise, and the rest from the non-tax state revenue, so it can be assured that the government will strive to optimize the tax revenue. ${ }^{1}$ In order to pursue these targets

Safri, "Efektifitas Program Tax Amnesty dan Faktor Keberhasilannya: Pembelajaran dari Negara-Negara yang Pernah Menerapkan", Jurnal Mitra Manajemen, Vol. 8 No. 2, 2016, Jakarta: Universitas Suryadarma, page 105106. government attempted to implement various policies, supervision, fostering awareness of paying taxes to the community as a consequence of the self assessment system, so there should be a willingness from the taxpayers to pay their tax obligations, ${ }^{2}$ and prevention of crimes against the tax sector, especially for tax evaders. Ignorance of taxes can be done through tax avoidance by utilizing the cracks of the laws and tax regulations, and tax evasion

2 Tedi Permadi, dkk, "Studi Kemauan Membayar Pajak Pada Wajib Pajak Orang Pribadi yang Melakukan Pekerjaan Bebas (Kasus Pada KPP Pratama Tampan Pekanbaru)", Jurnal Ekonomi, Vol. 21 No. 2, June 2013, Riau: Faculty of Economy Universitas Riau, page 3. 
that are contrary to tax regulations, if it is found in the tax assessment, there will be penalty according to applicable regulations. ${ }^{3}$ One of the government's efforts to overcome tax evasion is tax amnesty policy enforcement. In the specified time period, this policy gives room for the taxpayers to be able to pay off their tax liability with compensation in exemption from interest sanctions, penalties, and criminal charges. ${ }^{4}$

The current government enforce latest tax amnesty policiy which is Law No. 11 Year 2016 concerning Tax Forgivenss (Tax Forgiveness Act), better known as the tax amnesty legislation or tax amnesty which was ratified on July 1,2016 . The definition of remission of tax under this Act is the abolition of the tax owed will not be punished with tax administration sanction and criminal sanction in the field of taxation, by uncovering their treasures and paying the ransom determined.

This policy comes amid warming Papers Panama issues related to the taxpayer data originating from Indonesia indicated tax evasion in Panama Papers document. Finance Minister at that time revealed that before the data Panama Papers leaked to the public, the government has to first have the data names of Indonesian people who have assets abroad and the possibility of tax evasion in tax haven countries (tax havens). This data was obtained from G20 member states by the end of 2015. Furthermore, the Finance Minister said there is potential for the property of the taxpayer around Rp.4,000 trillion, which has not been affected by the tax. Approximately USD 1,400 trillion is a wealth of pre-tax and remitted to the Directorate General of Taxation, while the remaining Rp.2,700 trillion, is the property of the Indonesian personnel that are stored in a number of banks abroad. Law Enforcement Tax Forgiveness is the government's efforts to attract all the funds to Indonesia.

3 Urip Santoso dan Justina M. Setiawan, "Tax amnesty dan Pelaksanaannya di Beberapa Negara: Perspektif Bagi Pebisnis Indonesia”, Jurnal Sosiohumaniora, Vol. 11 No. 2, July 2009, Bandung: Universitas Padjajaran, page 112.

4 Safri, Op.Cit., page 106.
Tax Forgiveness Act is basically intended to increase state revenue from taxes and increase the tax ratio, in order part of the tax reform program by structuring tax management system. Against this Tax Forgiveness Act either before or after promulgation can not be separated from the pros and cons in the community. Counter parties feel that this policy has damaged justice and counterproductive to the spirit of the rule of law. In view of Article 23A of the 1945 Constitution states that taxes and other charges for the purposes of coercive state governed by law. This means that paying taxes is an obligation for every taxpayer, and Article 11 (5) of the Tax Forgiveness Act governing compensation to be obtained by the subject of tax amnesty, that the subject of the tax which has been published for (already paid the ransom and have submitted statements treasure), obtained a tax amnesty in the form of elimination of withholding taxes that have not issued tax assessments do not sanction tax administration, is not subject to criminal sanctions in the field of taxation, and no assessment of tax. In the development of even the Constitutional Court has received 3 petition for judicial review on Law Tax Forgiveness in Case 57/PUU-XIV/2016, 58/ PUU-XIV/2016 and 59/PUU-XIV/2016, There is also a contradictory regulations related to the immune protection of data subject access tax amnesty that is not grounds to investigate, and/ or criminal prosecution against the taxpayer. Then the relevant officials and other parties related to the implementation of the Tax Forgiveness, can not be reported, sued, investigation, investigation, or prosecution, both civil and criminal under Article 20 and Article 22 of Tax Forgiveness Act. The pro or supports the view that the tax amnesty is a new source of economic growth amid the global economic slowdown and to optimize that infrastructure into development priorities. Amid the pros and cons that occurred related to the implementation of the policy tax amnesty both in law Forgiveness Taxes and regulations related instance, interesting to examine whether the policy is important as a means of building a tax system that is new in the context of tax reform, and are as- 
sociated with forgiveness for tax evaders if the terms of elements of the legal system whether this policy could potentially abusive authority.

\section{Discussion}

Based on historical perspective, some countries implement the program tax amnesty covering South Africa, Argentina, Australia, Belgium, Colombia, Ecuador, France, Honduras, India, Ireland, Italy, Panama, the Philippines, United States, Denmark, Mexico, the Netherlands, Norway, Peru, Sweden and West Germany. ${ }^{5}$ South Africa, Ireland, and India are examples of countries that succeeded in the application of tax amnesty.

Indonesia has implemented a policy that is part of the tax policy tax amnesty Manesty ie 1964, 1984, 1994, and the sunset policy in 2008. The policy applies after it was sunset policy in 2008. The policy sunset policy is part of a tax amnesty include removing sanctions against the interest of tax administration. While on the subject of tax that has not been taxed, must be repaid by Taxpayers. ${ }^{6}$

The sunset policy in 2008 is deemed quite successful as it can realize a revenue target of 106.84\% (target 534520 trillion, trillion reached 571 106). Realization of revenues for 2008 is the only achievement that exceeds tax revenue target in the last 10 years. ${ }^{7}$ The sunset policy then continues in 2015, put into effect from May 1, 2015 until December 31, 2015.

\section{Considering The Urgency of Tax Amnesty}

Tax amnesty is a policy in the field of taxation which is patterned to provide incentives in the form of the elimination of tax principal that should be payable, administrative sanction or criminal tax on non-compliance has been done

5 Urip Santoso dan Justina M. Setiawan, Op.Cit., page 112

6 P. Helen Wijaya, "The Sunset Policy, Pengampunan Pajak yang Diharapkan?, Integrity: Jurnal Akuntansi dan Keuangan”, Vol. 2 No. 1, April 2008, Tangerang: Faculty of Accounting Economics Universitas Pelita Harapan, page 319.

7 Herry Setyawan, "Memunculkan Kembali Wacana Pengampunan Pajak (Tax amnesty)", Majalah Media Keuangan, Vol. X No. 90, March 2015, Jakarta: Secretariat General Kementerian Keuangan Republic of Indonesia, page 47.
Taxpayers in the past in order to improve compliance and as a way to increase revenues in the future come as tax amnesty provides an opportunity for the taxpayer to enter or return to the tax administration system that have an impact on improving reception in the future. Purposes of applying the tax amnesty in addition to increasing compliance and receiving countries, is also expected to have positive impact on investment with the transfer of funds/ capital from abroad into the country (capital inflow/ repatriation capital). ${ }^{8}$

Generally, the type of tax amnesty can be: Amnesty insisted that the principal payment of tax, including interest and penalties, and only remit tax criminal sanctions; Amnesty that require payments of principal past taxes owed with interest, but forgive penalties of fines and criminal sanctions taxes; Amnesty insisted that the principal payment of tax, but forgive sanctions interest, financial penalties, and criminal sanctions taxes; Amnesty for tax principal in the past, including interest penalties, fined, and criminal penalties. ${ }^{9}$

While setting tax amnesty under Law Forgiveness Tax is a taxpayer can receive the reduction and elimination of taxes that should have been due, not sanction tax administration in the form of interest and penalties hikes and criminal sanctions in the field of taxation, by way of uncovering treasures that have not been reported and paid ransom taking into account the debt associated with the assets that have not been reported.

Taxpayers who follow a policy of tax amnesty must submit an affidavit to the Minister of Finance that at least contain information on the identity of the taxpayer, assets, debts, net property value, and counting the ransom. Taxpayers must meet the requirements relating to the administration, among others, have a Tax Identification Number (NPWP), pay a ransom, pay

\footnotetext{
Ibid, page 46.

9 Bintoro Wardiyanto, Kebijakan Pengampunan Pajak (Tax amnesty) [Perspektif Kerangka Kerja Implementasi Sunset Policy mendasarkan UU No 28 tahun 2007], Jurnal Masyarakat Kebudayaan dan Politik, Vol. XXI No. 4 October-December 2008, Surabaya: Faculty of Social and Political Science Universitas Airlangga, page 329.
} 
off tax arrears, and pay off the tax or no pay or repay the tax that should not be returned to the taxpayer who is being examined preliminary evidence and / or investigation. ${ }^{10}$

Tax Forgiveness Act determines the subject and object of taxation as stipulated in Article 3. Subject of tax refers to any Individual Taxpayer, Corporate Taxpayer, Taxpayer engaged in the Micro, Small and Medium Enterprises (UMKM), Individual or Agency that is not yet as a taxpayer, by reporting th assets they have and pay the ransom except for taxpayers who are under investigation for criminal offenses in the area of taxation and file the investigation has been declared complete by the Attorney, for taxpayers who are in the process of criminal justice of taxation, or Taxpayers who are undergoing criminal penalties taxation. This tax amnesty in the form of remission of tax obligations until the end of the last tax, which has not or not yet fully completed by the taxpayer. The objects of tax amnesty such as income tax liability, and value added tax and sales tax on luxury goods.

Based on data from the Directorate of Ge-neral of Tax (Ditjen Pajak), tax amnesty in ef-fect since Tax Forgiveness Act was declared un-til March 31, 2017, and is divided into three (3) periods, namely: Period $\mathrm{I}$ is the date enacted until 30 September 2016; Period II is from the date on October 1, 2016 until December 31, 2016; and Period III from the date of January 1, 2017 until March 31, 2017. This three period is also related to the adjustment of payment de-termination of ransom that have to be paid by taxpayers. For Taxpayers of UMKM is as high as $0.5 \%$ to a maximum of 10 billion of assets, while for assets above 10 billion is around $2 \%$. Tax-payers who declare their assets located abroad and repatriate or refund to Indonesia adjusted to three periods that have been set as follows: 1 period rates of $2 \%, 3 \%$ second period and third period is $5 \%$. Whereas for taxpayers who declare their assets abroad

10 Wiwin Sri Rahyani, "Pengampunan Pajak (Tax Amnesty) Suatu Solusi Meningkatkan Penerimaan Pajak", Jurnal Rechts Vinding Online, upload 16 September 2016, apply in http://rechtsvinding.bphn.go.id/?page=home, accesed 18 September 2016, page. 3. but are not repatriated, ac-cording 3 specified period is equal to $4 \%, 6 \%$ and $10 \%$.

The Facilities that will be obtained by the taxpayer who follows the tax amnesty program include: the elimination of taxes that should be payable, administrative sanctions, and criminal sanctions, which has not issued yet the tax provisions; elimination of administrative sanctions on the tax assessment that has been issued; no tax audit, preliminary evidence examination and investigation of Crime in the Field of Taxation; termination of tax audit, preliminary evidence examination and investigation of Crime in the Field of Taxation, in which case the taxpayer is being carried out the tax audits, preliminary evidence examination and investigation of Crime in the Field of Taxation; and Elimination Final income on transfer of treasure in the form of land and/ or buildings and also investments.

In addition to setting facilities for taxpayers who follow the tax amnesty, Tax Forgiveness Act also specifies the consequences that must be followed by taxpayers, including Treasure repatriated which shall be invested into the country for 3 years since transferred in the form of: securities of the Republic of Indonesia; bonds of State Owned Enterprises (BUMN); bond financing institution owned by the Government; financial investment in the Bank's perception; pri-vate companies that trade bonds overseen by the Financial Services Authority; infrastructure investment through government cooperation with business entities; real sector investment based on the priorities set by the Government; and/ or other forms of investment constituted under the provisions of the legislation. Treas-ures revealed by the taxpayer cannot be trans-ferred abroad for 3 years from the issuance of Certificate about the tax amnesty.

About Tax Forgiveness Act, the Ministry of Finance has issued several regulations as provisions to implement the Tax Forgiveness is the Finance Minister Regulation (PMK) Number 118/ PMK.03/2016, PMK Number 119/PMK.03/2016 and the Decree of the Minister of Finance (KMK) Bumber 600 Year 2016. Then on August $23^{\text {th }}$, 
2016 issued by the PMK Number: 127/PMK. 010/2016 on Tax Forgiveness Based on Law Number 11 Year 2016 concerning Tax Forgiveness For Taxpayers Who Have Hidden Indirect Through a Special Purpose Vehicle.

Referring to the data from Directorate General of Taxation (Ditjen Pajak) until August 9, 2016 the progress of the numbers tax reporting related to tax amnesty has found 1,924 people who make a statement treasure with treasures reportedly reached Rp.12.6 trillion. Data that includes Rp.10.2 trillion declaration in the country, Rp.1.62 trillion declaration overseas and Rp. 744 billion repatriation. However, with the enactment and implementation of policies in the form of Tax Forgiveness Act and related regulations, is an appropriate solution as a means of establishing a new tax system in order to reform taxation so Tax Forgiveness Act be important to be declared. If the terms of the weak global economic conditions and low income countries, the answer is important even though it is less sense of fairness if the review facilities subject to tax amnesty, though not denying the state would get the revenue the state in large numbers in a short period of short-term benefits, but in long-term have a positive impact on state revenues from taxes that are critical in supporting the development, otherwise it will add a new taxpayer and reduce the potential for tax evasion.

The provisions of Article 2 of Tax Forgiveness Act mention that the tax amnesty is implemented based on the principle of legal certainty, fairness, expediency and national interests and aims to accelerate growth and economic restructuring through the transfer of assets, that will have an impact on the increase in domestic liquidity, improved exchange rate, decline interest rates, and increased investment; encourage tax reform towards a more equitable tax system and the expansion of the data base of taxation that more valid, comprehensive, and integrated; and increase tax revenues, among others, will be used to finance the construction. But there are some contradictory things related to the principle of Tax Forgiveness Act with the provisions contained that are about the prin- ciple of justice. On one side of this policy is intended to increase state revenue from taxes and increase the tax ratio as well as realizing the objectives described in Article 2 of Tax Forgiveness Act. On the other hand, these policies harm the principles of justice and contra productive to the spirit of the rule of law. In view of Article 23A of 1945 Constitution states that taxes and other fees that are forced for the purposes of the state governed by law, and the provisions of Article 1 paragraph 1 of Law Number 28 Year 2007 concerning Third Amendment of Law Number 6 Year 1983 concerning the General Rules and Procedure of taxation that taxes are mandatory contributions to the state owed by private persons or entities that are enforceable under the Act, by not getting the rewards directly and used for the purposes of the state for the welfare of the people. This means that paying taxes is an obligation for every taxpayer. Tax amnesty is seen giving different treatment to fellow citizens in this case the taxpayer is abiding by the Taxpayer efforts tax evasion, thus contrary to Article 27 paragraph (1) that "All citizens are equal under the law and government and shall abide law and the government, without exception." and Article 28D (1)" Everyone has the right to recognition, security, protection, and legal certainty and equal treatment under the law". Then provisions seen as contradictory to the principle of justice that is another advantage of the subject of tax amnesty obtained pursuant to Article 11 (5) of Tax Forgiveness Act set an amount of compensation or facilities to be acquired subject of tax amnesty, although regulates the consequences for the subject of tax amnesty to repatriate wealth into the country in the form of investment.

Fairness in taxation policy can be seen from justice in the relations between the government and the taxpayer, and the fairness of the allocation of the tax burden on the various segments of society. ${ }^{11}$ In a legal perspective according to Radbruch, the law should meet the

\footnotetext{
11 Amin Purnawan, "Rekonstruksi Sistem Pemungutan Pajak Penghasilan (PPh) Badan Berbasis Nilai Keadilan", Jurnal Dinamika Hukum, Vol. 11, Special edition, February 2011, Purwokerto: Faculty of Law Universitas Jenderal Soedirman, page 39.
} 
basic values that include fairness, usefulness (zweekmaszigkeit) and legal certainty. ${ }^{12}$ Meanwhile, according to Lawrence Friedman, elements of the legal system is comprised of legal structures, legal substance and legal culture. ${ }^{13}$ The legal structure includes the executive, legislative and judicial branches of government as well as related institutions, such as the Attorney, the Police, the Courts, the Judicial Commission, the Corruption Eradication Commission (KPK) and others. While the substance of the law is the norm, regulation or legislation. The substance of the law in this case is the Law of Forgiveness Tax if it is associated with the legal structure in this case the executive and legislative policy makers, a policy of tax amnesty is still found some contradictory to the provisions of law other and even if it is associated with the basic values of justice, there are several articles that contrary to the 1945 Constitution as noted previously. Contradictory to legislation other at least with regard to the provisions of Article 20 of Tax Forgiveness Act that the data and information sourced from Statement and its attachments are administered by the Ministry of Finance or other parties related to the implementation of this Act cannot be used as the basis for investigation, investigation and or criminal prosecution to the taxpayer. Then Article 22 which provides that the Minister, Deputy Minister, employees of the Ministry of Finance, and other parties related to the implementation of Forgiveness Tax, cannot be reported, sued, investigation, or prosecution, both civil and criminal if the duty is based in good faith and in accordance with the provisions of the legislation.

In the implementation of this provision will potentially lead to discrepancies in the provisions of several laws including the Law of Provisions and Tax Procedures, Law Number 8 Year 2010 concerning Money Laundering (TPPU), and Law Number 10 Year 1998. Basically the tax amnesty which the data can be traced investiga-

\footnotetext{
12 Tedi Sudrajat, "Problematika Penegakan Hukuman Disiplin Kepegawaian", Jurnal Dinamika Hukum, Vol. 8 No. 3 September 2008, Purwokerto: Faculty of Law Universitas Jenderal Soedirman, page 216.

13 Ibid.
}

tors linked only three things include cases of hu-man trafficking (trafficking), drugs, and terror-ism. Outside of those three things is not permit-ted and the investigator can only investigate based on the evidence obtained by its ownself without using data of tax amnesty. This is cer-tainly not in line with the values of justice and legal certainty and can potentially abuse au-thority in the sense of misusing the procedures that should be used to achieve certain goals, but have used other procedures to be carried out. ${ }^{14}$ Such policies should be consistent with the purpose of the administration set Article 3 of Law Number 30 Year 2014 concerning Gov-ernment Administration Purpose of the Law on Public Administration is to create orderly organ-ization of Government Administration; creating legal certainty; prevent abuse of authority; en-sure the accountability of the Agency and or Government Officials; provide legal protection to society and government officers; implement the provisions of the legislation and implement the General Principles of Good Governance; and provide the best possible service to society. Another is the potential abuse of authority on the tax implementing agency itself so that the role of the Financial Services Authority (OJK) as the executing supervision order tax amnesty can run optimally.

\section{Conclution}

The fundamental problem of taxation in Indonesia is a low tax ratio and management of the tax system that has not laid out well, especially in tackling tax evasion efforts. Tax amnesty aimed at the country's revenue in a short time. The tax amnesty is part of the tax reform program. Even appear the pros and cons but the tax amnesty policy is considered necessary in order to state income injected in large quantities and in a short time, adding a new tax payer and is expected to minimize the potential for tax avoidance. Regardless of contradictory pol-

\footnotetext{
14 Benny Irawan, "Diskresi sebagai Tindak Pidana Korupsi: Kajian Kriminologi dan Hukum terhadap Fenomena Pejabat Otoritas", Jurnal Mimbar (Jurnal Sosial dan Pembangunan), Vol. XXVII No. 2, December 2011, Bandung: P2u-LPPM Universitas Islam Bandung, page 148.
} 
icy, which is less sense of fairness if the terms of short-term benefits and are vulnerable to abuse of authority, but if it is managed by the professional management and human resources in the long term will have a positive impact on state revenues from taxes are very important in support of development.

The main controlling from the Financial Services Authority (OJK) as the competent institutions for the implementation of the tax amnesty is very important in view of the provisions of Article 11 (5), Article 20 and Article 22 and the Law of Tax Forgiveness is potential for the abuse of authority of the taxes executive apparatus. Other regulations related legislation procedures of the general provisions of taxation also needs to be passed as a series of tax reform program. Socialization, readiness and professionalism of apparatus for implementing the tax is a key to success of the implementation of this tax amnesty.

\section{References}

Irawan, Benny. "Diskresi sebagai Tindak Pidana Korupsi: Kajian Kriminologi dan Hukum terhadap Fenomena Pejabat Otoritas". Jurnal Mimbar (Jurnal Sosial dan Pembangunan). Vol. XXVII No. 2. December 2011. Bandung: P2u-LPPM Universitas Islam Bandung;

Permadi, Tedi. dkk. "Studi Kemauan Membayar Pajak Pada Wajib Pajak Orang Pribadi yang Melakukan Pekerjaan Bebas (Kasus Pada KPP Pratama Tampan Pekanbaru)". Jurnal Ekonomi. Vol. 21 No. 2. June 2013. Riau: Faculty of Economics Universitas Riau;

Purnawan, Amin. "Rekonstruksi Sistem Pemungutan Pajak Penghasilan (PPh) Badan Berbasis Nilai Keadilan". Jurnal Dinamika Hukum. Vol. 11. Special edition. Februari 2011 Purwokerto: Faculty of Law Universitas Jenderal Soedirman;

Rahyani, Wiwin Sri. "Pengampunan Pajak (Tax Amnesty) Suatu Solusi Meningkatkan Penerimaan Pajak". Jurnal Rechts Vinding Online. upload 16 September 2016. Available on http://rechtsvinding.bphn.go.id/? page=home. Accessed on 18 September 2016;
Safri. "Efektifitas Program Tax Amnesty dan Faktor Keberhasilannya: Pembelajaran dari Negara-Negara yang Pernah Menerapkan". Jurnal Mitra Manajemen. Vol. 8 No. 2. 2016. Jakarta: Universitas Suryadarma;

Santoso, Urip dan Justina M. Setiawan. “Tax amnesty dan Pelaksanaannya di Beberapa Negara: Perspektif Bagi Pebisnis Indonesia”. Jurnal Sosiohumaniora. Vol. 11 No. 2. July 2009. Bandung: Universitas Padjajaran;

Setyawan, Herry. "Memunculkan Kembali Wacana Pengampunan Pajak (Tax am-nesty)". Majalah Media Keuangan. Vol. X No. 90. March 2015. Jakarta: Secretariat General Kementerian Keuangan Republic of Indonesia

Sudrajat, Tedi. "Problematika Penegakan Hukuman Disiplin Kepegawaian". Jurnal Dinamika Hukum. Vol. 8 No. 3. September 2008. Purwokerto: Faculty of Law Universitas Jenderal Soedirman;

Wardiyanto, Bintoro. Kebijakan Pengampunan Pajak (Tax amnesty) [Perspektif Kerangka Kerja Implementasi Sunset Policy mendasarkan UU No 28 tahun 2007]. Jurnal Masyarakat Kebudayaan dan Politik. Vol. XXI No. 4. October-December 2008. Surabaya: Faculty of Social and Political Science Universitas Airlangga;

Wijaya, P Helen. "The Sunset Policy. Pengampunan Pajak yang Diharapkan?. Integrity: Jurnal Akuntansi dan Keuangan”. Vol. 2 No. 1. April 2008. Tangerang: Faculty of Accounting Economics Universitas Pelita Harapan. 